\title{
Soybean Seedcoat Mottling: Association with Soybean mosaic virus and Phomopsis spp. Seed Infection
}

\author{
G. Koning and D. M. TeKrony, Department of Agronomy, and S. A. Ghabrial, Department of Plant Pathology, \\ University of Kentucky, Lexington 40546
}

\begin{abstract}
Koning, G., TeKrony, D. M., and Ghabrial, S. A. 2003. Soybean seedcoat mottling: Association with Soybean mosaic virus and Phomopsis spp. seed infection. Plant Dis. 87:413-417.

Soybean mosaic virus (SMV) infection predisposes soybean (Glycine max) seed to Phomopsis spp. seed infection and may induce seedcoat mottling. The extent of seedcoat mottling associated with the accumulation of SMV or Phomopsis spp. infection of the seedcoat was investigated in 1996 and 1997. Plants of two SMV-susceptible cultivars, 'Clark' and 'Williams', were sap inoculated with the G2 strain of SMV at growth stage R2. Control plants (SMV-resistant isolines L78-434 and L78-379, respectively) were not inoculated. Harvested seed were evaluated visually for seedcoat mottling and sorted into four categories (severe, banded, blemish, and none) according to the degree of seedcoat pigmentation. Seed infection with Phomopsis spp. was determined and SMV accumulation was assessed by enzyme-linked immunosorbent assay and nucleic acid hybridization analysis. Phomopsis spp. were isolated from seed of all mottling categories, with the incidence of infection increasing as the degree of seedcoat mottling increased. SMV was detected in both mottled and nonmottled seedcoats, with generally higher levels of SMV in mottled seedcoats. However, the relationship of SMV titer to seedcoat mottling was inconsistent across cultivars and years. Thus, the extent of seedcoat mottling was not directly related to the accumulation of SMV in the seedcoat.
\end{abstract}

It has been well documented that Soybean mosaic virus (SMV) infection of soybean plants (Glycine max (L.) Merr.) may induce seedcoat mottling $(16,19,22,30)$. Seedcoat mottling has been described as the accumulation of anthocyanins or leucoanthocyanins in irregular patches, blotches, or bands of black or brown pigments in the epidermal layer of yellow or green seedcoats $(28,31)$. The incidence and severity of seedcoat mottling depends partly on the virus strain and host genotype, the time and incidence of SMV infection, mixed infection with other viruses, and environmental conditions $(2,4,16,22,23)$.

Seedcoat mottling is also under genetic control $(1,30)$, and is most visible when the gene combinations result in a colored hilum. Cooper (8) reported that a single dominant gene $(\mathrm{Im})$ was responsible for mottling resistance and that genotypes containing this gene were immune to SMV-induced seedcoat mottling, regardless of the environment. Only those genotypes genetically susceptible to mottling (im im) demonstrated seedcoat mottling. Five independent genetic loci, $I, R, W, O$, and $T$, have been reported to control the

Corresponding author: D. M. TeKrony

E-mail: dtekrony@uky.edu

Accepted for publication 14 November 2002.

Publication no. D-2003-0210-01R

(C) 2003 The American Phytopathological Society color and distribution of the pigment $(2,20)$.

Soybean plants infected with SMV may produce mottled seed which exhibit a range of seedcoat mottling or pigmentation (14). In addition, the infection of soybean with SMV may predispose seed to Phomopsis spp. infection $(12,15,16,24,26)$. The association between the extent of mottling and the level of SMV and Phomopsis spp. seed infection remains uninvestigated. The objective of this study was to examine the association between the degree of seedcoat mottling and (i) the incidence of Phomopsis spp. seed infection and (ii) the level of SMV accumulation in the seedcoat.

\section{MATERIALS AND METHODS}

Two SMV-susceptible soybean cultivars ('Clark' and 'Williams') and their SMVresistant isolines (L78-434 and L78-379, respectively) were field grown during 1996 and 1997 at the University of Kentucky Agricultural Experimental Station farm at Lexington. Seed of the isolines were obtained from their originator, R. L. Bernard (United States Department of AgricultureAgricultural Research Service and Department of Agronomy, University of Illinois, Urbana). Cultivars susceptible to SMV were inoculated at growth stage R2 (9) with the Kentucky isolate of SMV strain G2 (7), used in previous studies $(16,22,29)$. The SMV inoculum was prepared by grinding young, SMV-infected soybean leaves in $0.05 \mathrm{M}$ potassium phosphate buffer $(\mathrm{pH} 7.4)$ at a ratio of 1:5 (wt/vol) in a blender (22). Infected leaves were obtained from infected plants that were grown in the greenhouse. Carborundum was added to inoculum and the mixture was rubbed onto all three leaflets of a newly developed leaf. Plants showing symptoms of SMV (17) were tagged for harvesting. The resistant lines were not inoculated because they are known to be highly resistant to SMV strain G2; no symptoms were observed and no virus was detected in mechanically inoculated plants or in plants exposed to natural infection under conditions where SMV was rapidly spreading (22).

Phomopsis spp. inocula were applied to all plants as described by Koning et al. (16). The source of Phomopsis spp. inocula was Phomopsis-infested stems and residue, collected from the previous seasons' soybean fields, which were scattered on the soil surface between plants and rows at R2 (10). Additionally, a Phomopsis spp. spore suspension, prepared from cultures grown on acidified ( $\mathrm{pH} 4.5)$ potato dextrose agar (aPDA) for 14 to 21 days, was atomized (25) onto plants at R5.

Seed were harvested at maturity (140 g $\mathrm{kg}^{-1}$ seed moisture) and visually sorted and grouped into four discrete categories based on the extent of seedcoat pigmentation (Fig. 1). Fifty seed of each mottling category and cultivar were arbitrarily selected

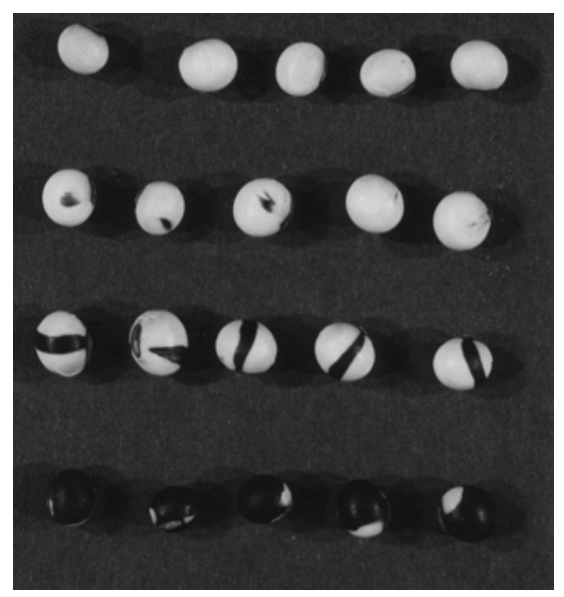

Fig. 1. Examples of seed in four distinct categories of soybean seedcoat mottling, where None $=$ no visual seedcoat mottling; Blemish $=$ 5 to $10 \%$ seedcoat is pigmented; Band $=25$ to $30 \%$ seedcoat is pigmented, typically with one solid band encircling the seed, extending from one side of the hilar region to the other; and Severe $=>70 \%$ seedcoat is pigmented. 
and bisected (each half consisting of a cotyledon and its seedcoat-half). One seedhalf was evaluated for Phomopsis spp. infection, after incubation for 14 days on aPDA (pH 4.5) at $25^{\circ} \mathrm{C}$ under continuous light as described by TeKrony et al. (27), and the other seed-half was evaluated for the accumulation of SMV antigen in the seedcoat, using the direct form of enzymelinked immunosorbent assay (ELISA; 11).

Seedcoat extract dilutions which produce ELISA absorbance values that fall within the linear phase of the standard sigmoid curve, generated with purified (6) virion concentration (10 to $1,000 \mathrm{ng} / \mathrm{ml}$ ) versus absorbency readings, were used. Accordingly, dilutions of $1: 150$ and 1:60 (wt/vol; seedcoat: extraction buffer) were used for ELISA testing of individual and bulked seedcoat samples, respectively. To ascertain whether the routine use of bulk samples of seedcoats (five half-seedcoats, approximately $50 \mathrm{mg}$ fresh wt., tested at a dilution of 1:60 wt/vol) in the ELISA procedure interfered with the accurate assessment of SMV accumulation in the mottled seedcoats possibly due to the aggregation of viral particles, higher dilutions (1:120 and 1:600 wt/vol) of the bulked seed also were tested by ELISA and results compared with those obtained with individual seedcoats ( $\pm 20 \mathrm{mg}$ fresh weight) of each of five seed from each cultivar and mottling category.

Antigen concentration in the seedcoat samples was estimated by interpolation in the standard curve of purified virion concentration versus ELISA readings. Seedcoats from SMV-resistant plants (Clark isoline L78-434; determined in previous tests to yield negligible ELISA readings; 16) were used as the negative control and leaves from SMV-susceptible plants showing symptoms of SMV were used as the positive control in ELISA tests.

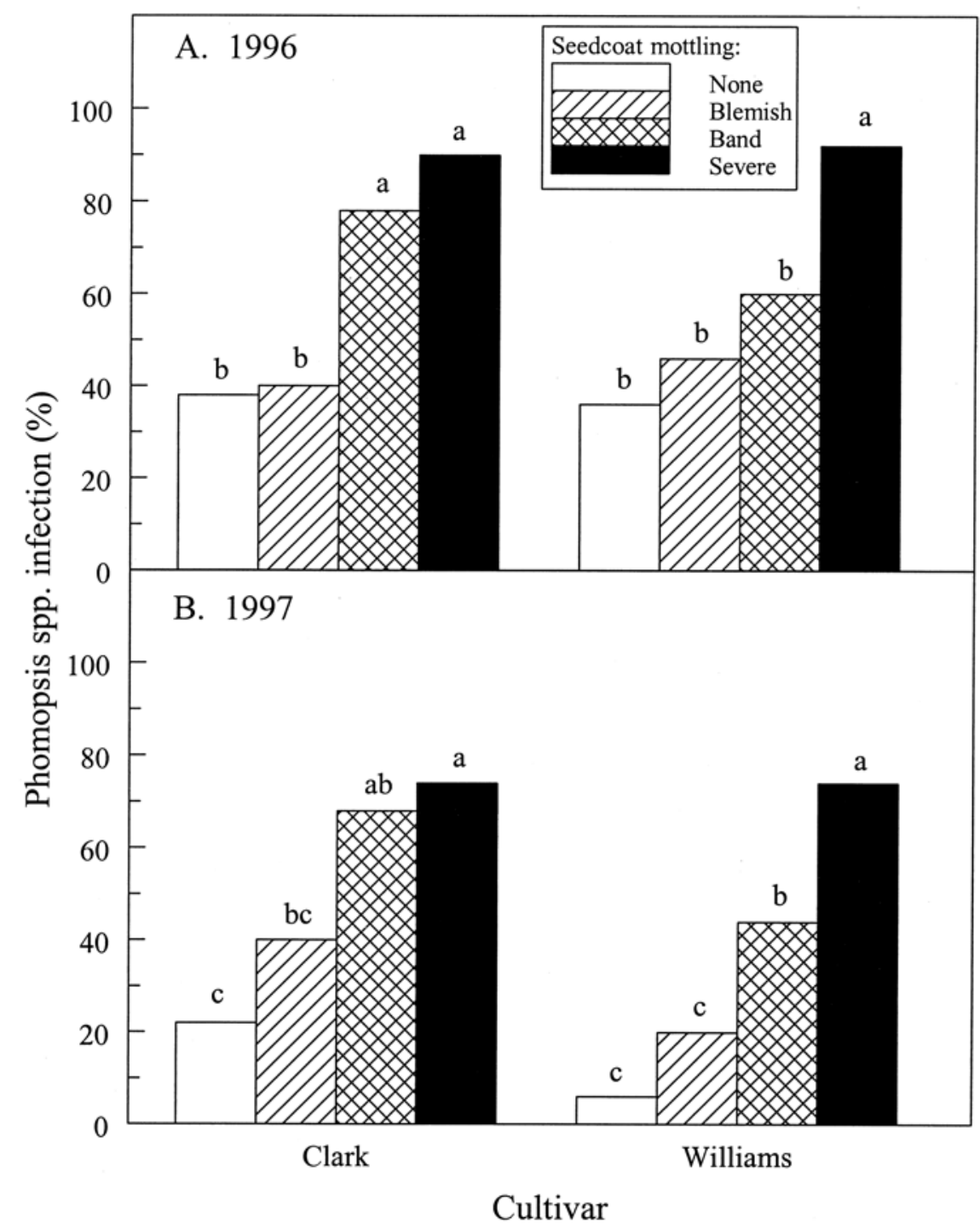

Fig. 2. Incidence of Phomopsis spp. seed infection of seed sorted into different levels of seedcoat mottling in A, 1996 and B, 1997. None = no visible seedcoat mottling; Blemish $=5$ to $10 \%$ seedcoat is pigmented; Band $=25$ to $30 \%$ seedcoat is pigmented, typically with one solid band encircling the seed, extending from one side of the hilar region to the other; and Severe $=>70 \%$ seedcoat is pigmented. Bars with different letters within cultivars are significantly different $(P<0.05 ; n=50)$.

In addition to the ELISA assays, three replications of nucleic acid hybridization analyses were conducted in 1997 to determine the level of SMV RNA in seedcoats. Viral RNA was extracted from 50 seedcoats of seed of three mottling categories labeled none, band, and severe (Fig. 1), using seedcoats of SMV-resistant seed (Clark isoline L78-434) as the negative control. Total RNA extracts were prepared as previously described (29). The RNA extracts were heated at $70^{\circ} \mathrm{C}$ for $5 \mathrm{~min}$, chilled on ice, and transferred and fixed onto Hybond-N membrane (Amersham, Piscataway, NJ) according to the manufacturer's instructions. Procedures for preparation of radiolabeled nick-translated cloned cDNA probes to SMV RNA and conditions for prehybridization, hybridization, and membrane washes were as described by $\mathrm{Hu}$ et al. (13). The membranes then were air dried and exposed to a phosphorimager screen (Molecular Dynamics, Sunnyvale, CA) for 2 to $5 \mathrm{~h}$. The images were visualized by a PhosphorImager 445 SI system and analyzed with the FragmeNT Analysis 1.1 program (Molecular Dynamics). The ELISA data were analyzed as a one-way treatment classification in a completely randomized design using the general linear models procedure (PROC GLM) of SAS (version 6.03; SAS Institute, Inc., Cary, NC) and differences between treatments were determined using the least significant differences (LSD) procedure.

\section{RESULTS}

Seed of the two SMV-susceptible soybean cultivars and their SMV-resistant isolines were produced in the same environment during two consecutive years. A high percentage (30 to $88 \%$ ) of mottled seed were harvested from SMV-infected susceptible cultivars, whereas a negligible number of mottled seed $(<1 \%)$ were harvested from the SMV-resistant isolines (L78-434 and L78-379).

Seed of SMV-susceptible cultivars were sorted into four levels of mottling (Fig. 1), and each level was evaluated for Phomopsis spp. infection and the accumulation of SMV antigen. The incidence of Phomopsis spp. seed infection increased as the degree of seedcoat mottling increased, in both Clark and Williams cultivars across both years (Fig. 2). The incidence of Phomopsis spp. infection was consistently lowest in nonmottled seeds (6 to $38 \%$ ), and increased in seeds with blemished or banded mottling to 20 to $40 \%$ and 44 to $78 \%$, respectively. The incidence of infection was consistently highest in severely mottled seed, with 74 to $92 \%$ of the seeds infected with Phomopsis spp.

Using the ELISA procedure, SMV antigen was detected consistently in both nonmottled and mottled seedcoats, regardless of whether seedcoats were assayed as a bulk-seedcoat sample (Fig. 3A and B) or 
on an individual seedcoat basis (Fig. 3C and D). Across both years and genotypes, the higher dilutions of the bulk-seedcoat samples consistently yielded proportionally lower ELISA readings (data not shown), and possible interference with the accurate assessment of SMV accumulation due to the aggregation of viral particles was ruled out.

The concentration of SMV antigen, as estimated by ELISA in the bulk-seedcoat samples, was not consistently related to the extent of seedcoat mottling (Fig. 3A and B). In 1996 (Fig. 3A), the Clark nonmot- tled and blemished seed had approximately two to three times more SMV antigen compared with the Clark banded and severely mottled seed. In contrast, nonmottled Williams seedcoats had approximately half the amount of SMV antigen compared with Williams seed with blemished or

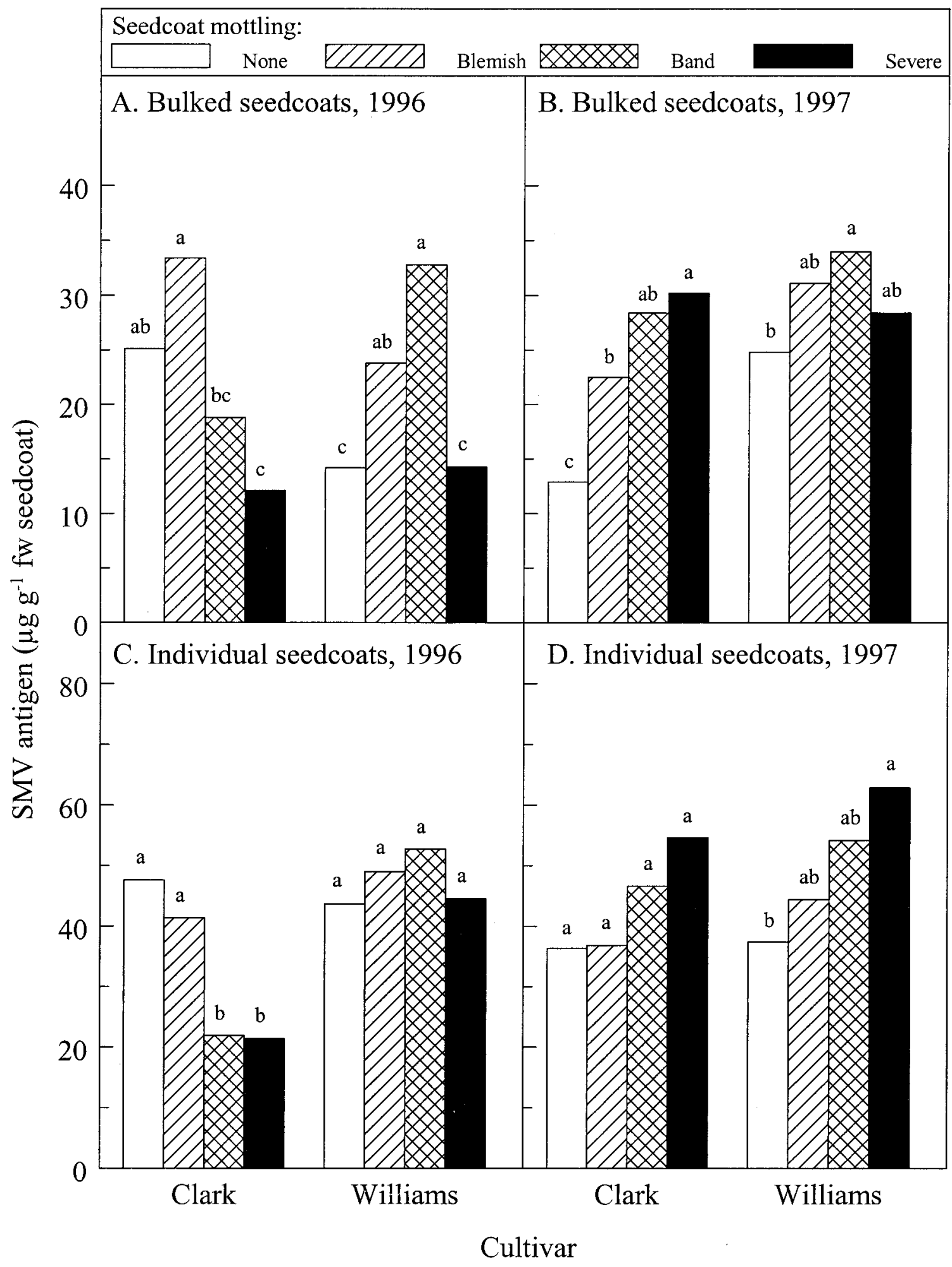

Fig. 3. Accumulation of Soybean mosaic virus (SMV; $\mu \mathrm{g} \mathrm{g} \mathrm{g}^{-1}$ ) detected by enzyme-linked immunosorbent assay in seedcoat samples of Clark and Williams in different seedcoat mottling categories. Concentration of SMV in bulked seedcoat samples $(n=50)$ in A, 1996 and B, 1997, and mean concentration of SMV in individual seedcoats $(n=5)$ in $\mathbf{C}, 1996$ and $\mathbf{D}, 1997$. None $=$ no visible seedcoat mottling; Blemish $=5$ to $10 \%$ seedcoat is pigmented; Band $=25$ to $30 \%$ seedcoat is pigmented, typically with one solid band encircling the seed, extending from one side of the hilar region to the other; and Severe = $>70 \%$ seedcoat is pigmented. Bars with different letters within cultivars, are significantly different $(P<0.05)$. 
banded seedcoats and did not differ significantly from the amount detected in severely mottled seedcoats. In 1997 (Fig. 3B), nonmottled Clark seedcoats consistently had the lowest concentration of SMV antigen $\left(13 \mu \mathrm{g} \mathrm{g}^{-1}\right)$ compared with the mottled seedcoats. Higher (nonsignificant) levels of SMV antigen accumulation also were detected in Williams as the degree of mottling increased with the highest level of SMV detected in the banded seedcoats.

The level of SMV antigen accumulation detected by ELISA in individual seedcoats (Fig. 3C and D) did not differ significantly between nonmottled and blemished seedcoats. In 1996 (Fig. 3C), the concentration of SMV in banded and severely mottled Clark seedcoats was approximately $50 \%$ lower than in nonmottled Clark seedcoats. However, no apparent differences were detected in the concentration of SMV in seedcoats of Williams seed of different mottling categories. In contrast, in 1997
(Fig. 3D), the mean concentration of SMV antigen in individual seedcoats increased as the degree of mottling increased, although the increases were mostly insignificant for both cultivars. The level of SMV accumulation in seedcoats from nonmottled Williams seed was approximately $40 \%$ less than in seedcoats from severely mottled Williams seed. Across both genotypes in 1997, the highest concentration of SMV (55 to $63 \mu \mathrm{g} \mathrm{g}^{-1}$ ) was detected in the severely mottled individual seedcoats; however, these levels were not significantly higher than the banded and blemished categories.

As expected, slot-blot hybridization analyses (Fig. 4) showed no hybridization with total RNA from the SMV-resistant control seed (L78-434). Hybridization signals of varying densities, however, were detected with total RNA from both the mottled and nonmottled susceptible Clark and Williams seedcoats. The evaluation of the band densities in Figure 4 revealed

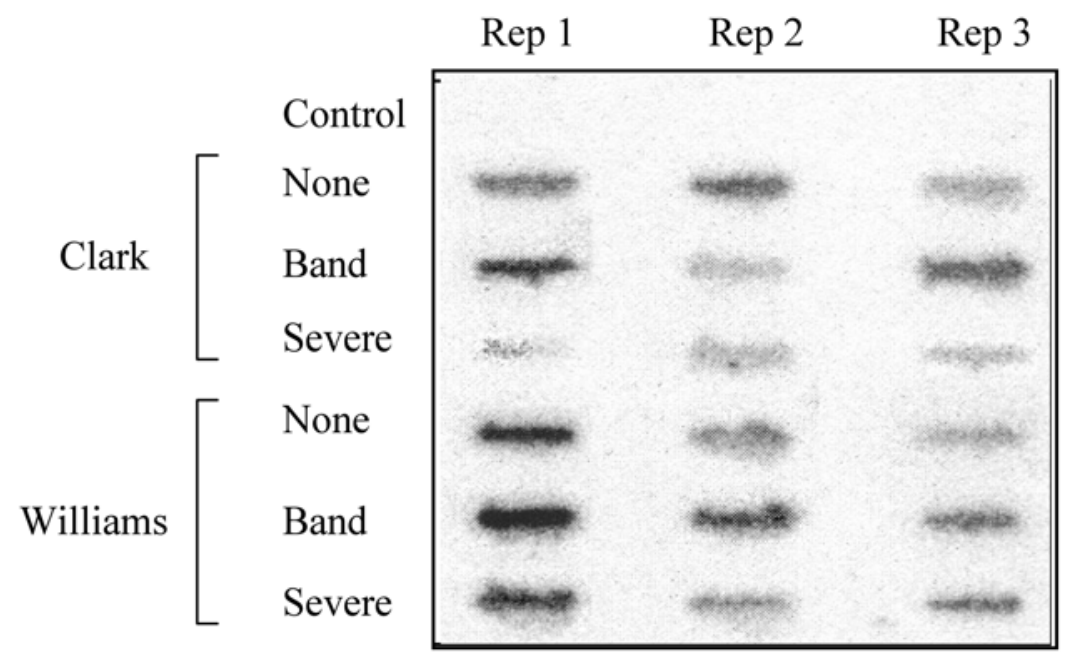

Fig. 4. Slot-blot hybridization analysis of total RNA extracted from seedcoats grouped in different seedcoat mottling categories in $1997(n=50)$. Control $=$ seedcoats of Clark Soybean mosaic virusresistant isoline (L78-434) seed, with no visible seedcoat mottling; None = no visible seedcoat mottling; Band $=25$ to $30 \%$ seedcoat is pigmented, typically with one solid band encircling the seed, extending from one side of the hilar region to the other; and Severe $=>70 \%$ seedcoat is pigmented in seedcoats of susceptible Clark and Williams.

Table 1. Analysis of RNA bands detected by slot-blot hybridization assay ${ }^{\mathrm{a}}$

\begin{tabular}{lcccc}
\hline & & \multicolumn{3}{c}{ Relative density $^{\mathbf{b}}$} \\
\cline { 3 - 5 } Genotype $^{\mathbf{c}}$ & Mottling category $^{\mathbf{d}}$ & Rep 1 & Rep 2 & Rep 3 $^{\text {Control }}$ \\
\cline { 3 - 5 } Clark & None & 1 & 1 & 1 \\
& None & 23 & 28 & 13 \\
\multirow{2}{*}{ Williams } & Band & 41 & 9 & 35 \\
& Severe & 4 & 13 & 7 \\
& None & 46 & 21 & 12 \\
& Band & 75 & 37 & 23 \\
\hline
\end{tabular}

a Slot-blot hybridization analysis of total RNA extracted from seedcoats grouped in different seedcoat mottling categories in $1997(n=50)$.

b Determined by FragmeNT Analysis software on a PhosphorImager (Molecular Dynamics Inc.).

${ }^{\mathrm{c}}$ Control $=$ Clark Soybean mosaic virus-resistant isoline (L78-434) with no visible seedcoat mottling.

${ }^{\mathrm{d}}$ None $=$ no visible seedcoat mottling; Band $=25$ to $30 \%$ seedcoat is pigmented, typically with one solid band encircling the seed, extending from one side of the hilar region to the other; and Severe $=>70 \%$ seedcoat is pigmented in seedcoats of susceptible Clark and Williams.

that, with the exception of second replication of the Clark cultivar, the level of SMV RNA accumulation in banded seedcoats was approximately twice that in nonmottled seedcoats (Table 1).

\section{DISCUSSION}

Even though assessment of SMV antigen accumulation in whole soybean seed has been previously reported (5), the focus of our study was on SMV antigen accumulation in the seedcoats in relationship to seed coat mottling and incidence of Phomopsis seed infection. Seedcoat infection is independent of host genotype and virus strain; therefore, SMV antigen accumulation in seedcoats can be detected in $100 \%$ of the seed collected from SMV-infected plants, as we have recently demonstrated (16). Although embryonic infection is a prerequisite for virus seed transmission, the rate of seed transmission (usually less than 10\%) and the distribution and level of SMV antigen accumulation in the various parts of the intact seed vary considerably with host cultivar, virus strain, and time of infection $(3,5,16)$. Seedcoats from SMVinfected plants thus provided more uniform material for addressing the objectives of our study.

Previous studies in our laboratory (14) and others $(19,30)$ have indicated an association between SMV infection and seedcoat mottling; however, the accumulation of SMV in seedcoats was not quantified. A positive association also was observed between the accumulation of SMV in the seedcoats and the percentage of mottled SMV-susceptible seed (14). As the percentage of mottled seed increased, the concentration of SMV antigen in the seedcoats increased. This relationship was explored further, and the accumulation of SMV in those seedcoats, which were pigmented to distinctly different degrees, was examined. Two approaches, serology (ELISA) and nucleic acid hybridization analyses, were used to detect SMV antigen and SMV RNA, respectively. Regardless of the approach used, SMV was detected in both the nonmottled and mottled seedcoats from susceptible cultivars. Therefore, plants infected with SMV produced mottled and nonmottled seed, with SMV present in both types of seedcoats. When seedcoats were combined for testing, it was not possible to determine whether SMV was present in each individual seedcoat. However, when seedcoats were individually analyzed by ELISA, SMV was found in each sampled seedcoat, from both mottled and nonmottled seed, from SMV-infected plants. It should be noted that other viruses (e.g., Bean pod mottle virus [BPMV]), also may induce seedcoat mottling (23). Thus, the presence of seedcoat mottling suggests that the seedcoats may be virus infected. However, in agreement with Pacumbaba (19), the absence of mottling clearly does not imply that seed are virus free. 
Generally, mottled seedcoats accumulated more SMV than nonmottled seedcoats. Analysis by ELISA did not show a consistent relationship between the degree of seedcoat pigmentation and SMV accumulation. The two soybean genotypes did not provide comparable results, either across or within years, or on an individual or bulked-seedcoat basis. Therefore, under the prevailing conditions of two environments and two genotypes, data relating the association between SMV accumulation in seedcoats and the degree of seedcoat mottling were inconclusive and suggested that the relationship is not a simple one.

A more distinct pattern was discerned using the more sensitive and specific nucleic acid hybridization analysis. Based on the intensity of the hybridization signal, nearly twice as much viral RNA was found in banded seedcoats (25 to $30 \%$ seedcoat was pigmented) than in those which were not pigmented. Less viral RNA was usually found in the seedcoats from severely pigmented seed $(>70 \%$ seedcoat was pigmented) compared with extracts from either nonmottled or banded seed. The reduced level of hybridization in severely mottled seedcoats could be due to the difficulties experienced during the extraction and isolation of total RNA, because the concentrated seedcoat extracts were highly viscous and difficult to resuspend. An inverse relation between virus accumulation and degree of seedcoat mottling also was observed with seed from some BPMVinfected soybean cultivars (John Hill, personal communication).

This study suggested that, when seedcoat mottling was associated with SMV infection and the environment was favorable for Phomopsis spp., a higher level of Phomopsis spp. seed infection could be expected in those seedlots with a higher incidence of mottled seed. In agreement with previously published reports $(8,21,30)$, all mottled seed, however, did not exhibit the same degree of pigmentation. Some seed were only slightly pigmented, others were severely mottled, and still others exhibited a banding pattern between the two extremes. Quite unexpectedly, the incidence of Phomopsis spp. seed infection increased as the seeds were progressively more pigmented and was positively associated with the extent of pigmentation (Fig. 1). However, seedcoat mottling was induced by SMV infection and SMV has been shown to be associated with an increase in Phomopsis spp. seed infection (14). Therefore, Phomopsis spp. infection is only indirectly associated with seedcoat mottling. However, mottling also has been shown to be under genetic and environmental control $(2,18,19)$, and apparently healthy (virus-free) plants yielded mottled seeds.

In summary, under the prevailing environments with the given host genotypes and virus strain, the incidence of Phomop- sis spp. seed infection increased as the percentage of mottled seed increased. This represents the first report of a positive association between the degree of seedcoat mottling and Phomopsis spp. seed infection. Furthermore, SMV was detected in both mottled and nonmottled seedcoats, with more virus usually accumulating in mottled than in nonmottled seedcoats. An increase in the degree of mottling, such that 25 to $30 \%$ of seedcoat was pigmented (banded), was generally consistent with an increase in SMV accumulation. At a higher level of mottling however, in the severely $(>70 \%)$ pigmented seedcoats, the association was no longer displayed, possibly due to difficulties during the extraction and preparation of protein and RNA samples. Thus, SMV accumulation in the seedcoats was not directly related to the degree of seedcoat mottling. Other factors, possibly genetic, are influenced by SMV infection and are involved in the production of seedcoat mottling.

\section{ACKNOWLEDGMENTS}

We thank the South African Foundation of Research and Development and the Research Challenge Trust of the University of Kentucky, for financial support for G. Koning; and W. Havens for laboratory assistance.

\section{LITERATURE CITED}

1. Anand, S. C., and Torrie, J. H. 1964. Heritability of frequency and intensity of seed coat mottling and smudginess and interrelationships with other traits in soybeans. Crop Sci. 4:185-186.

2. Bernard, R. L., and Weiss, M. G. 1973. Qualitative genetics. Pages 117-154 in: Soybeans: Improvement, Production, and Uses. 1st ed. B. E. Caldwell, R. W. Howell, J. W. Judd, and H. W. Johnson eds. Agron. Monogr. 16. ASA, CSSA, and SSSA, Madison, WI.

3. Bossennec, J. M., and Maury, Y. 1978. Use of the ELISA technique for the detection of soybean mosaic virus in soybean seeds. Ann. Phytopathol 10:263-268.

4. Bowers, G. R., and Goodman, R. M. 1991. Strain specificity of soybean mosaic virus seed transmission in soybean. Crop Sci. 31:1171-1174.

5. Bryant,, G. R., Hill, J. H., Bailey, T. B., Tachibana, H., Durand, D. P., and Benner, H. I. 1982. Detection of soybean mosaic virus in seed by solid-phase radioimmunoassay. Plant Dis. 66:693-695.

6. Calvert, L. A., and Ghabrial, S. A. 1983. Enhancement by soybean mosaic virus of bean pod mottle virus titer in doubly infected soybean. Phytopathology 73:992-997.

7. Cho, E.-K., and Goodman, R. M. 1979. Strains of soybean mosaic virus: Classification based on virulence in resistant soybean cultivars. Phytopathology 69:467-470.

8. Cooper, R. L. 1966. A major gene for resistance to seed coat mottling in soybean. Crop Sci. 6:290-292.

9. Fehr, W. R., and Caviness, C. E. 1977. Stages of soybean development. Spec. Rep. 80. Iowa Agric. Home Econ. Exp. Stn. Iowa State Univ. Ames.

10. Garzonio, D. M., and McGee, D. C. 1983. Comparison of seeds and crop residues as sources of inoculum for pod and stem blight of soybeans. Plant Dis. 67:1374-1376.

11. Ghabrial, S. A., and Schultz, F. J. 1983. Serological detection of bean pod mottle virus in bean leaf beetles. Phytopathology 73:480-483.
12. Hepperly, P. R., Bowers, G. R., Sinclair, J. B and Goodman, R. M. 1979. Predisposition to seed infection by Phomopsis sojae in soybean plants infected by soybean mosaic virus. Phytopathology 69:846-848.

13. Hu, C.-C., Aboul-Ata, A. E., Naidu, R. A., and Ghabrial, S. A. 1997. Evidence for the occurrence of two distinct subgroups of peanut stunt cucumovirus strains: molecular characterization of RNA3. J. Gen. Virol. 78:929-939.

14. Koning, G. 1999. Relationship between soybean mosaic virus and Phomopsis spp. infection of soybean seeds. Ph.D. diss. University of Kentucky, Lexington, KY (Diss. Abstr. 9948882).

15. Koning, G., TeKrony, D. M., Ghabrial, S. A., and Pfeiffer, T. W. 2002. Influence of Soybean mosaic virus (SMV) resistance gene (Rsv1) on Phomopsis spp. seed infection, in an aphidfree environment. Crop Sci. 42:178-185.

16. Koning, G., TeKrony, D. M., Pfeiffer, T. W., and Ghabrial, S. A. 2001. Infection of soybean with soybean mosaic virus increases susceptibility to Phomopsis spp. seed infection. Crop Sci. 41:1850-1856.

17. McGee, D. C. 1992. Soybean Diseases. American Phytopathology Society, St. Paul, MN.

18. Morrison, M. J., Pietrzak, L. N., and Voldeng, H. D. 1998. Soybean seedcoat discoloration in cool-season climates. Agron. J. 90:471-474.

19. Pacumbaba, R. P. 1995. Seed transmission of soybean mosaic virus in mottled and nonmottled soybean seeds. Plant Dis. 79:193-195.

20. Palmer, R. K., and Kilen, T. C. 1987. Qualitative genetics and cytogenetics. Pages 135-209 in: Soybeans: Improvement, Production, and Uses. 2nd ed. J. R. Wilcox, ed. Agron. Monogr. 16. ASA, CSSA, and SSSA, Madison, WI.

21. Porto, M. D. M., and Hagedorn, D. J. 1975. Seed transmission of the Brazilian isolate of soybean mosaic virus. Phytopathology 65:713-716.

22. Ren, Q., Pfeiffer, T. W., and Ghabrial, S. A.. 1997. Soybean mosaic virus incidence level and infection time: interaction effects on soybean. Crop Sci. 37:1706-1711.

23. Ross, J. P. 1969. Effect of time and sequence of inoculation of soybeans with soybean mosaic and bean pod mottle viruses on yields and seed characters. Phytopathology 59:1404-1408.

24. Ross, J. P. 1977. Effect of aphid-transmitted soybean mosaic virus on yields of closely related resistant and susceptible soybean lines. Crop Sci. 17:869-872.

25. Rupe, J. C., and Ferriss, R. S. 1987. A model predicting the effects of microclimate on infection of soybean by Phomopsis longicolla. Phytopathology 77:1162-1166.

26. Stuckey, R. E., Ghabrial, S. A., and Reicosky, D. A. 1982. Increased incidence of Phomopsis sp. in seeds from soybeans infected with bean pod mottle virus. Plant Dis. 66:826-829.

27. TeKrony, D. M., Egli, D. B., Balles, J., Tomes, L., and Stuckey, R. E. 1984. Effect of date of harvest maturity on soybean quality and Phomopsis sp. seed infection. Crop Sci. 24:189-193.

28. Todd, J. J., and Vodkin, L. O. 1993. Pigmented soybean (Glycine max) seedcoats accumulate proanthocyanidins during development. Plant Physiol. 102:663-670.

29. Wang, R. Y., and Ghabrial, S. A. 2002. Effect of aphid behavior on efficiency of transmission of Soybean mosaic virus by the soybeancolonizing aphid, Aphis glycines. Plant Dis. 86:1260-1264

30. Wilcox, J. R., and Laviolette, F. A. 1968 Seedcoat mottling response of soybean genotypes to infection with Soybean mosaic virus. Phytopathology 58:1446-1447.

31. Woodworth, C. M., and Cole, L. J. 1924 Mottling of soybeans. J. Hered. 15:349-354. 